\title{
Relocation of Children After Divorce and Children's Best Interests: New Evidence and Legal Considerations
}

\author{
Sanford L. Braver \\ Arizona State University
}

\author{
Ira M. Ellman \\ Arizona State University and \\ University of California, Berkeley
}

\author{
William V. Fabricius \\ Arizona State University
}

\begin{abstract}
Relocation cases, in which a divorced parent seeks to move away with the child, are among the knottiest problems facing family courts. The recent trend is to permit such moves, largely because of Wallerstein's (1995) controversial amica curiae brief, which a recent court (Baures v. Lewis, 2001) interpreted as supporting the conclusion that "in general, what is good for the custodial parent is good for the child" (p. 222). The current study provides the first direct evidence on relocation by dividing college students into groups on the basis of their divorced parents' move-away status. On most child outcomes, the ones whose parents moved are significantly disadvantaged. This suggests courts should give greater weight to the child's separate interests in deciding such cases.
\end{abstract}

Americans are a mobile people for whom moving is a relatively common experience. According to 2000 U.S. Census data, between March 1997 and March 1998, 16\% of all Americans moved (U.S. Bureau of the Census, 2000). About $43 \%$ of the movers left for a different metropolitan statistical area. The adults most likely to move are those between 20 and 34 years old, ages at which they are likely to have young children. ${ }^{1}$ Undoubtedly for that reason, children are, on average, more likely to move than are adults. Between March 1997 and March 1998, 23.5\% of all children between 1 and 4 years of age moved. Children between 5 and 6 moved at an annual rate of $17.9 \%$. Rates for older children were a bit lower.

People appear especially likely to move after their marriage fails. Ford (1997) showed that within 4 years of separation and divorce, about one fourth of mothers with custody move to a new location. In Braver and O'Connell's (1998) data set, 3\% of the custodial parents who could be located moved out of the area within 12 weeks of the divorce filing, $10 \%$ moved away within a year, and $17 \%$ moved within 2 years. As explained more fully below, among the college students surveyed for the current study

Sanford L. Braver and William V. Fabricius, Department of Psychology, Arizona State University; Ira M. Ellman, School of Law, Arizona State University and Earl Warren Institute, Boalt Hall School of Law, University of California, Berkeley.

We would like to acknowledge the assistance of Michael Lamb and Jason Williams.

Correspondence concerning this article should be addressed either to Sanford L. Braver, Department of Psychology, Arizona State University, Tempe, Arizona 85287-1104 or to Ira M. Ellman, School of Law, Arizona State University, Tempe, Arizona 852877906. E-mail sanford.braver@asu.edu orira.ellman@asu.edu whose parents had divorced, $61 \%$ experienced a move of more than one hour's drive by at least one parent at some time during their childhood; of the divorced sample, $25 \%$ moved with their custodial mother away from their father.

Postdivorce moves give rise to legal disputes primarily when the custodial parent seeks to move with the child and the other parent objects to the move's impact on his ${ }^{2}$ contacts with the child. This fact pattern is, therefore, the focus of this introductory discussion, but we later return to the companion case, in which the noncustodial parent relocates, leaving the custodial household behind.

Relocation disputes pose a considerable dilemma for courts (Kelly \& Lamb, 2003). They may pit a custodial parent's reasonable wish to better her circumstances by moving against a noncustodial parent's reasonable desire to maintain the frequent contact with his minor child that is a normal and perhaps essential element of any parental relationship. How the court should decide such cases has been a fertile source of dispute (Bruch \& Bowermaster, 1996; Elrod \& Spector, 1997; American Academy of Matrimonial Lawyers, 1998; Richards, 1999). The applicable legal rules have been unstable, as different courts and different states have struggled to develop coherent and just policies (American Law Institute, 2002, Reporter's Notes to Comment d, § 2.17). According to legal researchers (Bruch \& Bowermaster, 1996; Elrod \& Spector, 1997; Richards, 1999) some states' statutes declare a presumption permitting the reloca-

\footnotetext{
${ }^{1}$ Adults between 20 and 24 moved more frequently (34.2\%) than adults in any other age range, with those from 25 to $29(31 \%)$ and 30 to $34(22 \%)$ next most likely.

${ }^{2}$ Because about $85 \%$ of custodial parents are mothers (Meyer \& Garasky, 1993; Nord \& Zill, 1997), for convenience, but with some loss of accuracy, we refer to noncustodial parents with masculine pronouns and custodial parents with feminine.
} 
tion (e.g., Oklahoma, Tennessee, and Wisconsin), whereas others have a presumption precluding it (e.g., Montana and South Carolina). Some place the burden of proof on the parent desiring to relocate (e.g., Arizona, Alaska, and Arkansas); others place it on the parent opposing the move (e.g., California, Connecticut, and Louisiana). When courts have been called on to interpret these statutes or case law, they previously have generally restricted such moves (Terry, Proctor, Phelan, \& Womack, 1998), and some still hold there is a presumption against it (e.g., White v. White, 1994). However, the trend in court decisions in the past 5 years, beginning with the Burgess decision in California (In re the Marriage of Burgess, 1996; Shear, 1996), has clearly been to permit relocation (American Law Institute, 2002, Reporter's Notes to Comment d, § 2.17).

In coming to their decisions, courts consider the interests of both the parents and the child, which are, of course, intertwined (American Law Institute, 2002, § 2.02; Austin, 2000a, 2000b; Braver, Hipke, Ellman, \& Sandler, in press; Miller, 1995; Richards, 1999; Rotman, Tompkins, Schwartz, \& Samuels, 2000; Sample \& Reiger, 1998; Sobie, 1995). On the one hand, the better home that the custodial parent sees for herself in a new location can also be seen as a better home for the child. On the other hand, preserving the noncustodial parent's relationship with the child can be seen as an important interest of the child's as well as the parent's. As a strategic matter, both contesting parents are best off portraying their own interests as aligned with the child's, because the child's interests are normally regarded as the guidepost for all custody decisions, including relocation (American Law Institute, 2002, § 2.02). But understanding the dilemma facing courts in these cases requires examining separately each of these three interests.

The interest of the noncustodial parent is both obvious and substantial: retaining sufficient contact with his child to maintain a parental relationship. Significant physical separation that makes weekly or even monthly visits impractical is likely to add considerably to the difficulty of maintaining such a relationship. The interest of the relocating custodial parent can also be substantial. The move may be necessary to accommodate a new job for the custodial parent or it may be required to pursue an educational opportunity; perhaps she is moving in order to remarry or perhaps her new spouse is being transferred; maybe the move is contemplated to allow the custodial parent to live near friends or relatives available to provide that parent needed assistance or support. Both the noncustodial parent's interest in access to his child and the custodial parent's interest in choosing to move are substantial enough that governmental actions that burden either of them may, depending on the facts, be limited by federal constitutional principles. ${ }^{3}$

Of course, in any particular case we may have good reason to doubt the importance or sincerity of either parent's proffered interests. In some cases, the relatively short distance of the proposed move, or the child's relatively greater age, may suggest that the custodial parent's relocation would place no important burden on the noncustodial parent's relationship with the child. In other cases there may not be much relationship to burden: A noncustodial parent who has not taken advantage of his opportunities for time with his child when they both live in the same city is poorly positioned to argue that the child's relocation will unduly burden his right to maintain their relationship. Notice too that the proposed relocation may not burden the child's interests in these cases: In the first, the child's relationship with the parent left behind may continue unimpeded, and in the second, it may be largely absent in any event.

On the other side, some reasons for relocation are more compelling and legitimate than others. For example, the custodial parent with unpursued nearby employment prospects that are substantially equivalent to those available at the more distant situation (or whose new spouse has such prospects, where the new spouse's career is the occasion for the move) is differently situated than if relocation is truly necessary to realize a major career opportunity. Or compare the spouse with friends and family nearby, as well as in a distant location, with another who came only recently to the city she now wants to leave so that she can return to her former home, in which she has many relatives and close friends who are available to provide critical assistance. Once again, the interests of the child whose custodial parent has less compelling reasons to relocate seem themselves less likely to be furthered by the relocation, because there seems little reason to think the proposed home offers the child advantages over the present one. In short, sometimes an analysis of the interests of all parties will allow us confidently to conclude that this custodial parent should, or should not, relocate with the child.

Other cases are harder. Consider, for example, the custodial parent with sound reasons for seeking to move to a distant location that will in fact seriously impair a caring and involved noncustodial parent's access to his child. The New York Supreme Court, for example, has termed such relocation disputes to be among "the knottiest and most disturbing problems" (p. 736) courts face (Tropea $v$. Tropea,

\footnotetext{
${ }^{3}$ The constitutional protection afforded parents against arbitrary government action depriving them of access to their children is well established, arising in many contexts (see Ellman, Kurtz, \& Scott, 1998, pp. 1063-1093 [protection of unmarried father's parental right]; pp. 1337-1354 [termination of parental rights generally]). Most recently, the United State Supreme Court has held that parental rights are violated when a state court requires parents to allow third parties, including grandparents, access to their children merely because a judge decides that such access is in the child's best interests; parents alone have a right of access (Troxel $v$. Granville, 2000). The constitutional status of a right to travel or choose one's residence is more contested but clearly exists in some form and has been relied on by some courts in custody relocation cases (see, e.g., Jaramillo v. Jaramillo, 1991 [placing the burden of proof on the custodial parent is an unconstitutional impairment of the relocating parent's right to travel] and Holder v. Polanski, 1988 [allowing relocation unless adverse to child's best interests avoids the unconstitutional infringement on parent's right to travel], although even courts recognizing the applicability of a constitutional right to travel find that it yields when the child's interests so require, Everett v. Everett, 1995 [best interests of the child have priority over the parent's right to travel]).
} 
1996). Such cases inevitably result in a decision adverse to a parent with a good claim, because both parents have a good claim, insofar as their own interests are at stake. Here especially, then, the child's interests seem key, but intuition (so often relied on by appellate courts in devising rules) offers little guidance as to where those interests lie. Trustworthy empirical evidence concerning the impact of a custodial parent's long-distance moves on the children is thus critical to resolving the legal policy question.

There is, however, an even more fundamental problem, for it also turns out that cases that seem easy may actually be difficult for courts. Consider a case with facts like these: Both parents have a good relationship with their two children; Mom has primary custody and has always been the primary parent; and Dad, the family's primary breadwinner, works long hours incompatible with being the primary parent, although he is emotionally connected to his children, always makes full use of his visitation rights, and reliably pays his substantial child support obligation. The parents cannot realistically switch roles without a major financial sacrifice that will affect their children as well as themselves, because Mom's earning potential does not approach Dad's. Mom seeks to move several thousand miles away but offers no compelling rationale for the move, which the court reasonably suspects is truly motivated by her anger at Dad's remarriage. Dad cannot move to Mom's intended destination without an immediate and substantial sacrifice in income and without imposing severe dislocations on his new wife, who also has a career requiring her to remain where she is. Dad therefore opposes her relocation and persuades the court that it would seriously impair his relationship with his children and that Mom has no good reason for it.

Now consider the choices logically available to a judge asked to rule on Dad's objection to Mom's proposed move (the legally available choices may be fewer, as we note below): The court may (a) allow Mom to relocate with the children; (b) order primary custody changed from Mom to Dad, if Mom chooses to relocate (so that the status quo may or may not continue, depending on Mom's decision as to relocation); or (c) make no change in the custodial arrangements but instead tell Mom she may not move. It turns out that all of these choices are problematic. The first seems inadvisable because the court does not want to endorse the move. The second was once a fairly common response to a case like this, courts employing such orders strategically to deter relocation. Recent cases reject such a strategic use of change-of-custody orders, however, even though new evidence tells us that they are or would be effective as deterrents in nearly two thirds of cases (Braver, Cookston, \& Cohen, 2002).

These recent cases bar the use of conditional change-ofcustody orders as strategic tools to deter relocation because they require that such orders satisfy the requirements that govern ordinary petitions to change primary custody. ${ }^{4} \mathrm{Al}-$ though there is of course variation from state to state, as a general matter these requirements are fairly demanding. At a minimum, they would in this context bar a conditional change-of-custody order unless the court found that the children would be much better off, assuming the primary custodian relocates, remaining with Dad as the new primary custodian rather than moving with Mom to her new home. (Many states impose an even more demanding rule. ${ }^{5}$ ) And

${ }^{4}$ Jurisdictions do disagree about whether an order conditioning
continuation of primary custody on the parent's remaining at the
same residence must satisfy otherwise applicable modification
standards. Among those courts that have issued conditional orders
without determining whether the change of custody from one
parent to the other would be justified under the rules applicable to
custody modifications, see LaChapelle $v$. Mitten ( 2000 , upholding
court order conditioning mother's custody on her return to Min-
nesota); Maeda $v$. Maeda (1990; upholding court order granting
mother primary physical custody subject to transfer if she leaves
the court's jurisdiction); Lozinak $v$. Lozinak (1990; upholding
conditional order providing mother with continued physical cus-
tody only if she stayed in Pennsylvania, and otherwise primary
custody would change to father, under best interests test); Alfieri $v$.
Alfieri (1987, upholding court order that made continued custody
by mother contingent on return to New Mexico); see also Sullivan
v. Sullivan (1993; conditioning mother's custody on not moving,
even after the court determined that best interests of child would not be served by change of custody to father).

Courts holding that conditional awards may not be issued unless a change of custody would be warranted under the modification of custody standards include In re the Marriage of Burgess (1996; California statute provides no grounding for permitting court to test parental attachment by "bluff" that custody will change if parent relocates); Lamb v. Wenning (1992; move out of state by custodial parent does not justify change in custody unless the usual more stringent standard governing requests for change in custody - that the changed circumstances are so substantial and continuing as to make the existing custody order unreasonable-is met); Gould v. Miller (1992; to justify change of custody away from custodial parent, other parent must show significant change in circumstances plus adverse effect on child); Lane v. Schenk (1992; continued custody may not be conditioned on remaining in community, unless in light of the move, children's best interests would be so undermined that transfer of custody is necessary); Hensgens v. Hensgens (1995; change in custody to the nonrelocating parent not justified simply because the relocation would reduce contact with the child); Moore v. Moore (1991; change in custody would impose an "equally difficult" burden on custodial parent as on noncustodial parent). See also Taylor v. Taylor (1993; describing as "the worst of several possible alternatives" (p. 321) that mother, who was not allowed by the trial court to relocate to lowa, is living in an apartment in Memphis with child of former marriage and infant child of new marriage, separated from her new husband who goes to school in Iowa).

${ }^{5}$ Indeed, the legal burden placed on the party seeking to change primary custody can be more substantial. The Commissioners on Uniform State Laws have urged, since their adoption of the Uniform Marriage and Divorce (UMDA) Act in the early 1970's (National Conference of Commissioners on Uniform State Laws, 1974), that such petitions be rejected unless the movant can show that "the child's present environment endangers seriously his physical, mental, moral, or emotional health, and the harm likely to be caused by a change of environment is outweighed by its advantages" ( $\$ 409(b))$. State statutes adopting the UMDA standard include Colo. Rev. Stat. § 14-10-131(2) (1998); Ky. Rev. Stat. Ann. § 403.340(2) (Banks-Baldwin 1998); Ohio Rev. Code Ann. $\S$ 3109.04(E)(1)(a) (West 1995); see also Mont. Code Ann. 
that is a showing men like the Dad in our example are unlikely to be able to make. Parents who are primary custodians under existing court orders usually provide a home at least as good as that which the other parent would provide, and there is no obvious reason to think that as a general matter Mom's parenting ability will be so compromised by her move that shifting primary custody to Dad would become demonstrably superior for the child. Indeed, while the relocation-caused separation from Dad may be burdensome for the child, separation from Mom, who has been the child's primary caretaker during and after the marriage, might seem worse. And indeed, Dad may be reluctant even to seek a conditional change-of-custody order, from fear that Mom might call his bluff.

What Dad really wants, of course, is the third alternative: a simple order that Mom not relocate. As a general matter, however, such orders are not available. Courts generally regard themselves as having authority to decide whether the child can relocate, because at divorce the court assumes a responsibility for the child's welfare. It has no more authority over the parent's relocation, however, than over any other adult's choice of where to live. Cases like our example might suggest to some, however, that this limitation be reconsidered. Indeed, there is at least one state that does provide its courts statutory authority to prohibit a custodial

§ 40-4-219(1), (8) (1997) (same, without endangerment standard, and with additional grounds that child is at least 14 years of age and desires the modification, the custodial parent has interfered with noncustodial parent's exercise of visitation rights, or the parent has been convicted of one of a number of listed crimes relating to the child's welfare); Wash. Rev. Code Ann. § 26.09.260(2) (West 1997) (same, with addition that the nonmoving party has been found in contempt of court at least twice in the past 2 years or has been convicted of custodial interference in the first or second degree). Although other jurisdictions allow more flexibility, their general approach still favors maintenance of the status quo. Section 2.15 (1) of the American Law Institute's (2002) recently approved Principles of the Law of Family Dissolution recommends that the court limit nonconsensual changes in the custody arrangements to cases in which it finds

on the basis of facts that were not known or have arisen since the entry of the prior order and were not anticipated therein, that a substantial change has occurred in the circumstances of the child or of one or both parents and that a modification is necessary to the child's welfare. (p. 332)

Recommendations of the American Law Institute are often very influential with courts. For a comprehensive review of varying state rules on custody change, see the Reporter's Notes to Comment a of Section 2.15, which conclude that a clear majority of jurisdictions allow modification of custody only when there has been a substantial change in circumstances that establishes the modification is in the child's interests. This dominant approach is based on the plausible intuition that, other things being equal, changes in primary custody, or repeated petitions to change it, are not good for the child and ought to be discouraged in the absence of some reasonably compelling story. Applying such rules to our case would almost surely require rejecting any conditional changeof-custody order. parent's relocation, without changing the physical custody order, if it finds that the prohibition is in the best interest of the child (Wis. Stat. Ann., 1998).

Certainly, if one focused exclusively, or even primarily, on the child's interests, simple orders granting or denying a custodial parent's request to relocate might seem plausible. It may be that courts have not normally entertained them because they had no need to: Conditional change-of-custody orders served the same purpose, and in fact usually worked as intended to deter the relocation. There is no question that at one time many courts employed them in situations in which they simply assumed, probably correctly, that no change in custody would in fact ever take place because the custodial parent would not move. Some courts continue to employ them, despite the recent legal trend otherwise. ${ }^{6}$ If one were persuaded that the interests of children were served by such orders, one might believe that the recent trend is ill advised and should be reversed. Once again, then, evidence on the impact of parental moves on children seems key to the important policy choices courts are currently making in this area.

\section{Social Science Evidence and Relocation}

Unfortunately, in a recent review of the social science literature undertaken for the legal community (Gindes, 1998), not a single empirical study could be found containing direct data on the effects of parental moves on the well-being of children of divorce. In its absence, courts appear to have relied instead on quite indirect-and quite controversial-social science evidence about the potential effects of relocation on children. Even more troubling, this controversial evidence appears to have played an important role in generating the recent shift in legal doctrine away from restrictions on moves by custodial parents.

Consider the decision of the California Supreme Court In re the Marriage of Burgess (1996), an early and influential precedent in this legal shift, as noted earlier. At one time California had placed the burden on the relocating parent to prove that her move was in the child's best interest, and taking into account the noncustodial parent's ability to exercise visitation was a "significant consideration" in assessing that interest (see In re Carlson, 1991; Cooper v. Roe, 1993). In Burgess the court reversed itself, holding that the parent with primary custody has a presumptive right to move with the child, which can be overcome only if the other parent shows that changing custody from the relocating to the objecting parent "is essential or expedient for the welfare of the child" (In re the Marriage of Burgess, 1996, p. 482) because of a detriment the child would otherwise suffer that arises from the relocation.

As Warshak (2000) noted, the Burgess decision "closely echoed" (p. 83) an amica curiae brief filed in the case by pioneering divorce researcher Dr. Judith Wallerstein (1995;

\footnotetext{
${ }^{6}$ Sullivan v. Sullivan (1993; conditioning mother's custody on not moving, even after the court determined that best interests of child would not be served by change of custody to father).
} 
this was later adapted into a journal article: Wallerstein \& Tanke, 1996) arguing for a presumption in favor of relocation. In the absence of direct empirical evidence about the effects of parental moves on children of divorce, the brief attempted to infer the probable effects of relocation from the more general empirical literature on adjustment of children of divorce. However, Warshak (2000) claimed the brief contradicted "the broad consensus of professional opinion, based on a large body of evidence" (p. 85). He noted that the brief cites only 10 articles ( 7 from Wallerstein's own research group), whereas he identified a much larger pool of relevant articles that he claimed support a far different conclusion. He argued that "a comprehensive and critical reading of over 75 studies in the social science literature, including Wallerstein's earlier reports, generally supports a policy of encouraging both parents to remain in close proximity to their children" (Warshak, 2000, p. 84). He contended that Wallerstein has "shifted from her earlier position" (Warshak, 1999, p. 9) in the brief. He continued: "It is unclear what accounts for this shift, but the scientific literature does not justify it" (p. 9).

A very recent decision of the New Jersey Supreme Court, Baures v. Lewis (2001), again cites the social science literature rather extensively. It concluded that "most importantly, social science research links a positive outcome for children of divorce with the welfare of the primary custodian and the stability and happiness within that newly formed post-divorce household" and that recent "social science research has uniformly confirmed the simple principle that, in general, what is good for the custodial parent is good for the child" (Baures v. Lewis, 2001, p. 222). But a careful reading discloses that the social science articles cited in Baures are (with one minor exception, Tessman, 1978) confined to those cited in the Wallerstein and Tanke (1996) article. After reviewing them, the court observed that "as a result of all those factors, many courts have eased the burden on custodial parents in removal cases" (Baures $v$. Lewis, 2001, p. 224). Richards (1999), in reviewing court decisions nationally, termed Wallerstein's "a powerful and persuasive voice" in influencing court decisions and said her viewpoints are "credited with influencing [Tropea and Burgess, two influential state Supreme Court decisions] and reversing the national trend in relocation cases" (pp. 259-260).

What is the direct social science evidence concerning children's moves? A few studies exist reporting on the (generally deleterious) effects of parental relocation on nondivorced children (Humke \& Schaeffer, 1995; Jordan, Lara, \& McPartland, 1996; Levine, 1966; Stokols \& Shumaker, 1982; Tucker, Marx, \& Long, 1998). The most direct evidence to be found specifically with divorced children (Stolberg \& Anker, 1983) showed that a large number of "environmental changes," one item of which was parental relocation, predicted poor outcomes with divorced children, more so than with nondivorced children. Unfortunately, the effect of parental relocation was not broken out and specifically analyzed.

Clearly, courts ought to have better data than was available to the Burgess and Baures tribunals on the question of the impact of parental moves on the children of divorce. We present below new data that are far more direct than any previously in the literature.

Although evidence of short-term benefit or disruption to the child occasioned by the move would be useful and a greatly needed addition to the literature, more compelling still is evidence about more-enduring child outcomes. The short- and long-term impacts of a move on a child might not be the same. For example, moves might be initially disruptive for children but become positive or neutral in their impact longer term, once adjustments to the move have been made. In that case, sound policy might weigh the long-term effects more heavily than the move's transitional effects.

The current study provides some evidence of the longterm effects by examining the outcomes of young adults (college students) whose parents had divorced at some time during their childhood. For some, neither parent had moved very far from the intact family's home. We compared them, on various indices of current well-being, with the students with at least one parent who had moved more than an hour's drive away from the intact family's home. Among the indices we assessed are current measures of psychological and emotional adjustment, general life satisfaction, current health status, the relationship to and among the parents, and perceptions about having lived "a hard life." We also chose to assess the extent of financial help the students were currently receiving from their parents. Financial help is relatively objective, is of obvious interest to courts and policymakers, and could plausibly vary with moveaway status. Although a college student sample might introduce certain biases as compared with a more general young adult sample, as we explain below, these biases do not seem to be appreciable.

\section{Method}

\section{Respondents and Procedure}

Surveys were administered at a large Southwestern state university to nearly all students who were enrolled in introductory psychology classes in fall semester, 2001. All students present in each of the 15 sections on the administration day (in the second week of classes) were given a comprehensive research questionnaire sponsored by the Psychology Department, of which only a subset of questions relate to the current study. The 2,067 students responding were instructed to answer the items discussed below only if their parents were divorced and to skip these questions if their parents were not divorced. Students signed consent forms and were free to discontinue participation if they so chose, but few if any students did so. The 602 students who completed these questions and whose parents were thus divorced represented $29 \%$ of the total. Although it is certainly possible, if not probable, that young adult children of divorce who end up going to college at this state university are a biased subset of those whose parents divorce, it should be noted that the above percentage appears very representative. For example, Bumpass and Sweet (1989) found that almost the identical percentage, $31 \%$, of children whose parents are married are expected to experience parental divorce (see also comparable findings in the National Center for Health Statistics, 1990, Table 1-31). Thus, there is no clear evidence that the sample is self-selected and nonrepresentative of the general population of 
young adults whose parents earlier divorced. Of the total, $65 \%$ indicated they were paying in-state tuition, which runs $\$ 2,488$ per year, and $35 \%$ indicated they were paying out-of-state tuition, which is $\$ 10,354$. Total annual college costs are estimated on the official university Web site (http://www.asu.edu/admissions/ whyattendasu/costs.html) to be $\$ 11,794$ for in-state and $\$ 19,660$ for out-of-state students, respectively. It should be noted that the state is among those that do not allow their courts to require either parent to pay for the cost of attending college. Thus, for students whose parents were divorced in-state, any support either parent provides for college expenses is voluntary.

\section{Measures}

The primary predictor variable to be analyzed was students' response to the question regarding the moveaway status of their parents after the divorce. Specifically, respondents were asked, "Which of the following best describes whether either of your parents ever moved more than an hour's drive away from what used to be the family home?" Potential answer alternatives were that (1) neither ever moved that far away, (2) the mother moved and the respondent accompanied her, (3) the mother moved but the respondent remained with the father, (4) the father moved and the respondent accompanied him, or (5) the father moved but the respondent remained with the mother. To accommodate the possibility of both parents moving, each of the last four responses concerned which parent moved first; for example, the exact wording of alternative (5) was "Dad moved that far away at least once (but mom either never did or mom moved that far away after dad did); I stayed with mom."

A series of criterion variables were measured, some as multiitem scales, others as one-item measures. Parental contribution to college expenses was assessed by combining an item for each parent that asked, "How much money is your [mother's/father's] household (including [her/his] new [husband/wife] or live-in partner or [boy/girl]friend, if any) contributing to your total college expenses (tuition, books, room and board, fees, etc.) per year?" The potential responses included $0 ; 1-8$, which represented $\$ 1,000$ increments (e.g., $5=\$ 4,001-\$ 5,000$ ), and 9, which represented "more than $\$ 8,000$." The $1-8$ scores were recoded to the midpoint of the interval, and the 9 score (endorsed by $15 \%$ for mother's contribution and $17 \%$ for father's) was recoded to $\$ 9,000$. Note the result thus plausibly understates total contribution.

We also included measures of hostility and general physical health. Parental divorce has been shown to be associated with lower quality of parent-child relationships (e.g., Amato \& Booth, 1996) and marital conflict (Amato, 1993), and lower levels of perceived parental caring and exposure to parental conflict have been associated with the development of trait hostility (e.g., Luecken, 2000a; Matthews, Woodall, Kenyon, \& Jacob, 1996). A large literature exists linking the psychosocial characteristic of hostility with heightened risk for cardiovascular and other diseases and poorer prognosis following cardiac incidents (e.g., Barefoot, Larsen, von der Lieth, \& Schroll, 1995; Williams, 1997). Increased sympathetic reactivity to stress has been associated with hostility and may represent the biological mechanism by which hostility increases risk of coronary heart disease (e.g., Davis, Matthews, \& McGrath, 2000; Engebretson, \& Matthews, 1992; Kamarck et al., 1997). In general, parental divorce is stressful for many children (e.g., Wolchik, Sandler, Braver, \& Fogas, 1985), and evidence is mounting that stressful early childhood experiences, especially with caregivers, can have lasting effects on physical health (e.g., DeBellis et al., 1999) and on physiological stress reactivity and vulnerability to stress-related illness (e.g., Gunnar, 1998; Heim et al., 2000; Luecken, 2000b). Luecken and Fabricius (in press) found that young adult children of divorce who felt very negative about their parents' divorce showed higher hostility and more illness reports than those who felt more positive about the divorce. Goede and Spruijt (1996) found poorer health in young adult females from divorced families relative to intact families, but not in males. We selected nine items from the Cook-Medley Hostility Scale (Cook \& Medley, 1957) to assess trait hostility, rated from 0 (strongly disagree) to 3 (strongly agree). These items correlated best $(.71, p<.01)$ with the whole score in a stepwise regression. A typical item was "I have at times had to be rough with people who were rude or annoying." The standardized coefficient alpha was .64. We used a one-item measure of general health, "Would you say that in general your health is ..." with responses of $0=$ poor, $1=$ fair, $2=$ good, $3=$ very good, $4=$ excellent . Perceived general global health, as measured by single items such as this one, has been shown to be related to physical health and premature mortality (e.g., Idler \& Benyamini, 1997).

We used a one-item construct of general life satisfaction, patterned after the "Life 3" measure (Andrews \& Withey, 1976), which has been found to be highly valid and predictive of other measures of global life satisfaction. The item read, "Generally speaking, how satisfied are you with your life?," with responses of 0 (extremely dissatisfied) to 8 (extremely satisfied).

A vastly shortened version of the Personal and Emotional Adjustment-subscales of the Student Adaptation to College Questionnaire (SACQ) (Baker \& Siryk, 1989) scale was included to assess current adjustment levels. Specifically, the four items inquired about depressive symptoms and thought disturbances. These items, with a 0 (applies to me very closely) to 8 (doesn't apply to me at all) response format, were chosen because in preliminary analyses with a similar sample (Coatsworth, 2000) they correlated best with the whole subscale score in a stepwise regression. In the current data set, the coefficient alpha was adequate, .69. A final item from the same subscale of the SACQ, which inquired about worry over college expenses, lowered the alpha if included; accordingly, it was analyzed instead as a singleitem construct.

A vastly shortened version of the Painful Feeling About Divorce Scale (Laumann-Billings \& Emery, 2000) was included to assess inner turmoil and distress from divorce. Of the 38 original items, we asked 4, 2 from the Seeing Life Through the Filter of Divorce subscale ("I probably would be a different person if my parents had not gotten divorced" and "My parents' divorce still causes struggles for me") and 2 from the Loss and Abandonment subscale ("I had a harder childhood than most people" and "My childhood was cut short"). These items were asked with a 0 (strongly disagree) to 4 (strongly agree) response format used in the original. The coefficient alpha was marginal, .59.

Whether the respondent regarded his or her mother and/or father as a positive supporter and role model was explored with two 0 (not at all) to 8 (extremely) items each, devised specially for this purpose. They asked, "To what extent is your [mother/father] really there for you when you need [her/him] to be?" and "To what extent do you feel your [mother/father] is a good role model for you?" For mothers, the "good supporter" scale alpha was .84; for fathers, it was .93. When they were combined (added) into the "two good role models" scale, the alpha dropped to a marginal .56. As the latter was considered an effects rather than a causal indicator construct (Bollen \& Lennox, 1991), the low alpha was not deemed a cause for concern.

As single-item constructs, we asked, "I feel that the number of 
very close friends I have is the right number for me," "The kind of women (men) I am attracted to are unfortunately not very good for me," and "I feel I have a problem with drinking too much or using substances too much." In preliminary analyses with a similar sample (Coatsworth, 2000), the latter were each found to be the best single-item correlate with the full scales of the Platonic Relationship Choices, Romantic Relationships Choices, and Substance Abuse subscales, respectively. The latter were all answered on a 0 (applies to me very closely) to 8 (doesn't apply to me at all) response format. In addition, we included the single item "How well do your parents get along?" on a 0 (not at all well) to 8 (extremely well) format, designed especially for this investigation.

\section{Results}

The results are presented in Table 1 . In only $39 \%$ of cases did neither parent move. Of the remainder, relocating with the mother and the father relocating while the child remained with the mother were almost equally likely, constituting about $25 \%$ of the overall divorced sample each. The remaining two possibilities, remaining with the father while the mother relocated or relocating with the father, were comparatively rare, constituting only about $8 \%$ and $4 \%$ of cases, respectively.

Each criterion variable was analyzed with a one-way analysis of variance (ANOVA) (using variable-wise deletion) considering the five moveaway status situations. In addition to the overall or omnibus ANOVA $F$ test (reported in column a), four specific planned contrasts of special interest because of their policy implications and prevalence were conducted for each criterion variable. The first (in column b) compared the group for which neither parent moved with the average of all of the moveaway groups. Next, column c reports the results of a contrast comparing children's outcomes when they relocated with mother with when all family members remained near the original family home. This contrast assesses the outcomes in the circumstances courts are most often asked to decide. Column d reports analogous results when it was the father who moved and left mother and child behind. Finally, column e compares child outcomes for the most common relocation situations: when mother moves, taking the child with her, and when father moves, and mother and child remain behind. The final two contrasts address the question of who is the moving parent in the most common situation where the child and the mother remain together.

A number of criterion variables show no differences whatever, and these are mentioned first: Platonic relationship choices, romantic relationship choices, and current substance abuse problems appeared unrelated to moveaway status. The remaining 11 criterion variables showed at least some significant differences between moveaway status groups. First, children enjoyed significantly more financial support for their college expenses when there were no moves than in other conditions. They received over $\$ 1,800$ per year more in that circumstance than when they relocated

Table 1

Means for Outcome Variable, for Each of the Five Move-away Status Groups, and Significance Test Values

\begin{tabular}{|c|c|c|c|c|c|c|c|c|c|c|}
\hline \multirow[b]{2}{*}{ Variable } & \multicolumn{5}{|c|}{ Move-away status group } & \multirow[b]{2}{*}{$\begin{array}{l}\text { (a) } \\
\text { Omnibus } \\
\text { test }\end{array}$} & \multirow[b]{2}{*}{$\begin{array}{l}\text { (b) } \\
\text { (1) vs. }(2-5)\end{array}$} & \multirow[b]{2}{*}{$\begin{array}{l}\text { (c) } \\
\text { (1) vs. (2) }\end{array}$} & \multirow[b]{2}{*}{$\begin{array}{l}\text { (d) } \\
\text { (1) vs. (5) }\end{array}$} & \multirow[b]{2}{*}{$\begin{array}{l}\text { (e) } \\
\text { (2) vs. (5) }\end{array}$} \\
\hline & $\begin{array}{c}(1) \\
\text { Neither } \\
\text { moved }\end{array}$ & $\begin{array}{c}(2) \\
\text { I moved } \\
\text { with mom }\end{array}$ & $\begin{array}{l}\text { (3) } \\
\text { I remained } \\
\text { with dad }\end{array}$ & $\begin{array}{l}\text { (4) } \\
\text { I moved } \\
\text { with dad }\end{array}$ & $\begin{array}{l}\text { (5) } \\
\text { I remained } \\
\text { with mom }\end{array}$ & & & & & \\
\hline$N$ & 232 & 148 & 46 & 22 & 154 & & & & & \\
\hline$\%$ & 39 & 25 & 8 & 4 & 26 & & & & & \\
\hline $\begin{array}{l}\text { Total contribution to } \\
\text { college }(\$) \\
\text { Personal/emotional }\end{array}$ & 6,154 & 4,378 & 4,987 & 3,700 & 5,197 & .01 & .001 & .001 & .05 & $n s$ \\
\hline $\begin{array}{l}\text { adjustment } \\
\text { Hostility }^{\mathrm{a}}\end{array}$ & $\begin{array}{l}20.57 \\
11.75\end{array}$ & $\begin{array}{l}20.23 \\
11.42\end{array}$ & $\begin{array}{l}19.26 \\
13.59\end{array}$ & $\begin{array}{l}17.32 \\
13.68\end{array}$ & $\begin{array}{l}21.16 \\
12.11\end{array}$ & $\begin{array}{r}n s \\
.01\end{array}$ & $\begin{array}{l}.06 \\
.05\end{array}$ & $\begin{array}{l}n s \\
n s\end{array}$ & $\begin{array}{l}n s \\
n s\end{array}$ & $\begin{array}{l}n s \\
.05\end{array}$ \\
\hline $\begin{array}{l}\text { Inner turmoil and } \\
\text { distress from } \\
\text { divorce }\end{array}$ & 1.66 & 1.96 & 2.23 & 2.19 & 1.98 & .001 & .001 & .01 & .001 & $n s$ \\
\hline Mom good supporter & 11.99 & 12.33 & 8.65 & 7.14 & 12.54 & .001 & .001 & $n s$ & $n s$ & $n s$ \\
\hline $\begin{array}{l}\text { Dad good supporter } \\
\text { Two good role }\end{array}$ & 9.94 & 6.66 & 10.89 & 9.68 & 6.03 & .001 & .001 & .001 & .001 & $n s$ \\
\hline models & 21.90 & 19.08 & 19.77 & 16.82 & 18.56 & .001 & .001 & .001 & .001 & $n s$ \\
\hline Parents get along & 3.97 & 2.74 & 6.67 & 2.90 & 2.83 & .001 & .001 & .001 & .001 & $n s$ \\
\hline $\begin{array}{l}\text { Platonic relationship } \\
\text { choices } \\
\text { Romantic relationship }\end{array}$ & 5.50 & 5.52 & 5.24 & 5.05 & 5.35 & $n s$ & $n s$ & $n s$ & $n s$ & $n s$ \\
\hline choices & 2.91 & 2.91 & 3.20 & 3.05 & 3.13 & $n s$ & $n s$ & $n s$ & $n s$ & $n s$ \\
\hline $\begin{array}{l}\text { Substance abuse } \\
\text { Worry about college }\end{array}$ & 6.22 & 6.41 & 5.55 & 6.09 & 6.21 & $n s$ & $n s$ & $n s$ & $n s$ & $n s$ \\
\hline $\begin{array}{l}\text { expenses } \\
\text { Global health }^{\mathrm{b}}\end{array}$ & $\begin{array}{l}4.64 \\
2.80\end{array}$ & $\begin{array}{l}4.18 \\
2.62\end{array}$ & $\begin{array}{l}4.30 \\
2.66\end{array}$ & $\begin{array}{l}3.05 \\
2.48\end{array}$ & $\begin{array}{l}3.88 \\
2.76\end{array}$ & $\begin{array}{r}.05 \\
n s\end{array}$ & $\begin{array}{l}.01 \\
.05\end{array}$ & $\begin{array}{r}n s \\
.05\end{array}$ & $\begin{array}{c}.01 \\
n s\end{array}$ & $\begin{array}{l}n s \\
n s\end{array}$ \\
\hline $\begin{array}{l}\text { General life } \\
\text { satisfaction }\end{array}$ & 5.80 & 5.78 & 5.47 & 5.05 & 5.81 & $n s$ & .05 & $n s$ & $n s$ & $n s$ \\
\hline
\end{tabular}

${ }^{a}$ Also significantly interacted with gender: Girls were more hostile and boys were less hostile when dad moved than when both parents remained. ${ }^{\mathrm{b}}$ Also significantly interacted with gender: Girls were less healthy than boys in (2) than in (1). 
with their mother $\left(p<.001^{7}\right)$, and about $\$ 1,000$ more in that condition than when it was their father who moved $(p<$ .05 ). Additional analyses (not shown) show that father's share of this contribution is $58 \%, 35 \%, 72 \%, 69 \%$, and $41 \%$, respectively, in the five groups. It appears, thus, that fathers' voluntary support for college dropped off very noticeably when the child relocated with mother and that this loss was not made up for by increases mother made. Fathers' dropoff was not as dramatic when it was the father who moved, though this difference only approached significance $(p<$ $.07){ }^{8}$

Worry about college expenses showed similar but distinguishable effects (lower scores imply more worry). These young people worried more when it was their father who moved, and only the contrast of this from the neither-moved group was conventionally significant; the contrast of the mother-moved group from the neither-moved group approached significance $(p<.07)$.

In terms of their current reports of their personal and emotional adjustment, the groups appeared about equal except that in the two infrequent groups, where the youngster moved with or remained with the father, the respondent was noticeably less well adjusted. The same is true for general life satisfaction. Although a similar conclusion pertains to students' reported hostility levels, there was also a significant larger degree of hostility evident in students whose father relocated than in those who relocated with their mother. As the table note implies, this variable also had a significant interaction with child's gender: Girls were more hostile whereas boys were less hostile when their father moved than when both parents remained.

Results from the Inner Turmoil and Distress From Divorce Scale show many effects of moveaway status. Although the neither-moved group was lowest and the two infrequent statuses were highest, both moving away with mother and remaining with mother while father moved were significantly higher in distress than both parents remaining.

Students had better total rapport with their parents and saw both as role models significantly more when there had been no moves. In the three most common moveaway groups, rapport with mother stayed relatively constant; the above effect was instead due to dramatic dropoffs in their relationship with their father when either he moved or the respondent moved with their mother.

How well the parents got along showed a somewhat unusual pattern: It was much higher among the $8 \%$ who remained with their father while the mother moved. Among the remaining statuses, the parents' reported relationship was significantly better when neither parent moved than in any of the other moveaway situations.

Moreover, the student's reported level of general global health significantly differed by moveaway status. Global health was significantly lower when the student moved with his or her mother than when neither moved. It is also interesting to note that this effect significantly interacted with gender: It was primarily the female students who showed this diminution in health when they relocated away from their father with their mother.

Finally, we found that the student's report of the legal custody arrangement predicted moveaway status. Students were asked to report their legal custody arrangements with the following options: joint legal custody (both parents shared legal responsibility for making decisions for you), mother had sole legal custody (mother had legal responsibility for making decisions for you), father had sole legal custody (father had legal responsibility for making decisions for you), other, and don't know. In the $40 \%$ of families with joint legal custody, only $48 \%$ had any moves. This rose to $75 \%$ for the $38 \%$ of families with sole maternal legal custody and $69 \%$ for the $5 \%$ of families with sole paternal legal custody.

\section{Discussion}

Continuing policy debates over the best rules for deciding relocation disputes have been hampered by a lack of direct data on the long-term impact of parental moves on children of divorce. The present study begins to close this information gap. It provides a window into the relative outcomes for children whose parents move more than one hour's drive away from one another after their divorce. It does so by comparing families in which neither parent ever moved away with families, in which either the mother or the father moved with the child, as well as to families in which either parent moved without the child (who remained with the nonmoving parent). We evaluated the young adult child's outcomes on 14 variables representing financial and emotional support from parents, personal distress and adjustment, social relations, substance abuse, and physical health. These assessments represented somewhat long-term outcomes, in that our source of data was college students' reports about themselves and their divorced families. We acknowledge, of course, that findings from such a sample may misrepresent the long-term effect of relocation in a more general sample of divorced families, because college students from divorced families are probably a biased (i.e., more successful) subset of those from divorced families in general (although the rate of divorce among students' families was not substantially different from what has been estimated for the general population). It may well be, for

\footnotetext{
${ }^{7}$ All contrast $p$ values are one-tailed, because a direction was predicted.

${ }^{8}$ We explored parents' financial support for college in additional analyses of covariance (not shown) that controlled for parents' standard of living and for the type of tuition (in-state, out-of-state) that students reported paying. We measured standard of living by asking students to report on the current financial state of each of their parent's households. The details of how we asked this are given in Fabricius, Braver, and Deneau (2003). The only substantive differences were that the contrast between Groups 1 and 5 no longer reached significance and the contrast between Groups 2 and 5 approached significance $(p=.055)$. Thus, when equated for both of their parents' ability to pay, students received relatively more financial help for college when their fathers had been the ones to move away than when their mothers had moved and taken them away from their fathers.
} 
example, that a college sample is likely to include those who were least negatively affected by relocation. ${ }^{9}$

We find a preponderance of negative effects associated with parental moves by mother or father, with or without the child, as compared with divorced families in which neither parent moved away. On 11 of the 14 variables, there were significant (or, in one case, near-significant, $p=.06$ ) differences. As compared with divorced families in which neither parent moved, students from families in which one parent moved received less financial support from their parents (even after correcting for differences in the current financial conditions of the groups), worried more about that support, felt more hostility in their interpersonal relations, suffered more distress related to their parents' divorce, perceived their parents less favorably as sources of emotional support and as role models, believed the quality of their parents' relations with each other to be worse, and rated themselves less favorably on their general physical health, their general life satisfaction, and their personal and emotional adjustment $(p=.06)$. In some cases, the differences, although significant, are relatively modest. But in other cases they seem substantial. The students whose divorced parents had moved received, on average, considerably less financial help from their parents for their college expenses. They also rated the distant parent (mother or father) considerably less favorably as a source of emotional support, without regard to whether the distance arose from their move away from that parent or from that parent's move away from them.

In the great majority of these relocating families (82\%), the move separated the child from the father, because either the mother moved away with the child or the father moved away alone. ${ }^{10}$ Table 1 shows that the effects are remarkably similar in these two cases. The only exceptions are worry about college expenses (where greater deficits are associated with the father moving), hostility (where greater deficits are associated with the father moving for girls), and general global health (where greater deficits are associated with the mother moving for girls). The less common cases $(18 \%)$ in which the child and mother were separated, whether because the child moved with the father or the mother moved alone, similarly appear to have deficits compared with the nonmoving group.

We found that children were much less likely to experience either of their parents moving if they reported their parents had joint legal custody as opposed to sole maternal legal custody. The rates were $48 \%$ versus $75 \%$. (However, caution is needed here because the custody arrangement we used is the student's report, rather than examination of official records. There is thus the distinct possibility that these reports inaccurately represent the true legal custody arrangement in the divorce decree. Indeed, it is plausible that the accuracy of the report is confounded with moveaway status; for example, that those who move with their mother wrongly infer that their mother must have had sole custody.) It is noteworthy that a recent meta-analysis (Bauserman, 2002) of the published and unpublished research on custody arrangements concluded that children in joint custody arrangements are better adjusted than those in sole maternal custody on a variety of measures, including general adjustment, family relationships, self-esteem, emotional and behavioral adjustment, and divorce-specific adjustment. This suggests that future research should be aimed at determining whether parental relocation in sole maternal custody families contributes to children's greater maladjustment in those families.

The data also suggest potentially important physical health implications. The children of divorced parents who moved showed less favorable scores on several variables (hostility, parents getting along, inner turmoil and distress, parental support, and current global health) that may suggest future health problems for them. Higher hostility in college students has been found to predict greater coronary risk factors 21-23 years later (Siegler, Peterson, Barefoot, \& Williams, 1992), and high levels of family conflict have been associated with poorer physical health in adolescents (Mechanic \& Hansell, 1989). Other research suggests that childhood stress may have long-lasting influences on the development of physiological stress response systems important in long-term disease susceptibility (DiPietro, 2000). Poor quality parent-child relationships have been associated with higher blood pressure in undergraduate students (Luecken, 1998) and physical health status in middle-age adults (Russek, Schwartz, Bell, \& Baldwin, 1998). Finally, self-reported global health has been found to be a remarkably consistent predictor of premature mortality, even when controlling for numerous specific health indicators known to predict mortality (Idler \& Benyamini, 1997). Combined, it is reasonable to project that even greater and more serious deficits might be found in children of relocating parents the longer the term of the follow-up.

\section{Limitations and Interpretation}

Although these data are far more on point in evaluating relocation policies than any previously considered by courts, they are of course correlational, not causal. So whereas the data tell us that a variety of poor outcomes are associated with postdivorce parental moves, they cannot establish with anything near certainty that the moves are a contributing cause. It is certainly possible, if not likely, for example, that various preexisting (or self-selection) factors are responsible both for the parents' moving and for the child's diminished outcomes. Preexisting factors that could plausibly play this role include a low level of functioning for one or both parents, the inability of one or both parents to put the child's needs ahead of his or her own, and high

\footnotetext{
${ }^{9}$ We thank an anonymous reviewer for pointing this out.

${ }^{10}$ When children moved with the mother, students reported she was either the sole legal custodian or a joint legal custodian $87 \%$ of the time. When they moved with the father, he was either sole or joint custodian $67 \%$ of the time. When the father moved without the child, he was a custodian only $31 \%$ of the time, and when the mother moved without the child, she was a custodian $57 \%$ of the time. Students reported "some other" legal custodial arrangement or that they didn't know what their legal custodial arrangement was $12 \%, 24 \%, 18 \%$, and $17 \%$ of the time, respectively.
} 
levels of premove conflict between the parents (indeed, our finding that nonmoving parents are reported by their children to have significantly better relationships with each other is plausibly interpreted with such a causal sequence). Because research designs using random assignment to probe the causal connections are precluded by the nature of the subject matter, causation can be addressed only with longitudinal (or perhaps retrospective) data that control or equate for such potential selection factors. Collecting such longitudinal or retrospective data should be high on the research agenda for this topic.

In the absence of such longitudinal data, one must consider several alternative explanations for our results: (a) that moving per se tends to be harmful for children, (b) that families with characteristics that are harmful for children also tend to move, or (c) that both (a) and (b) are true. It is also logically possible (d) that parental moves are actually beneficial for children but tend to be undertaken primarily by families with characteristics that are harmful for children, so that while the children of divorced parents who move are, on balance, worse off than the children of divorced parents who do not, their disadvantage is smaller than it might otherwise have been had they not moved. Note that the data do appear to exclude what might otherwise seem an additional alternative, that divorced parents who are inclined to move away from one another are not, on average, more risky for their children than other divorced families, and that the parental move improves the children's situation. Had this possibility been valid, the moving groups would have had superior outcomes rather than the inferior ones found. This final possibility is excluded whether one focuses on parental moves in general or looks separately at moves by custodial parents or noncustodial parents.

That exclusion offers some help to policymakers in this area. General data on average effects cannot decide individual cases, of course. But the data can help the rulemaker, judicial or legislative, because it suggests that courts would be mistaken to assume, in the absence of contrary evidence, that children benefit from moving with their custodial parent to a new location that is distant from their other parent whenever the custodial parent wishes to make the move. Putting the point in legal terminology, the burden of persuasion in relocation disputes, on the question of whether the move is in the child's interests, should probably lie with the custodial parent who seeks to relocate rather than with the objecting parent. Decisions like Baures v. Lewis (2001) and In re the Marriage of Burgess (1996) reach the opposite conclusion because they appear to accept the proposition that children are aided by any move that their custodial parent believes desirable. The current data suggest, however, that this proposition can be true only if alternative (d) is the explanation for our data-that parental moves arise disproportionately among divorced families that are so dysfunctional that their children remain worse off than children of other divorced families, even after reaping the move's presumed benefits. The greater the benefit one presumes is conferred by the average move, the greater the family dysfunction one must presume on average precedes it, in order to explain how the move's purported benefit is concealed in the adverse outcomes that we found. We are not aware of evidence that would support the presumption that moving families are disproportionately so dysfunctional, although we are currently attempting to collect further data on this issue. For now, we are content to treat alternative (d) as less likely than the other explanations of our data.

Alternative (c) appears to us the most likely explanation of the data. In any event, it seems more likely than alternative (b) (that selection accounts for all of the poorer outcomes experienced by children whose divorced parents move), because of the repeated associations found, in a variety of contexts, between the amount of time spent with the noncustodial parent and the quality of the parent-adult child relationship. For example, Lye, Klepinger, Hyle, and Nelson (1995) reported that "the longer the adult child lived apart from the parent, the weaker are relations with the noncustodial parents" (p. 261). And it has been found that the less children saw their fathers while growing up, the less fathers contributed to their college expenses (Fabricius, Braver, \& Deneau, 2003) and the less close were the fathers' relationships with their adult children (Deneau, 1999; Fabricius, in press; Luecken \& Fabricius, in press). Finally, students report that both they and their divorced fathers generally wanted more time together (Fabricius \& Hall, 2000). The overall pattern thus seems consistent with a causal model in which custodial parent moves, even those made for good reasons, thwart the long-term relationship with the parent left behind, which in turn will in some respects impair the child.

Ultimately, however, our data cannot establish with certainty that moves cause children substantial harm. They do allow us to say, however, that there is no empirical basis on which to justify a legal presumption that a move by a custodial parent to a destination she plausibly believes will improve her life will necessarily confer benefits on the children she takes with her.

As noted earlier, some courts (e.g., Burgess, Baures), relying on Wallerstein and Tanke's (1996) summary of the social science literature to the effect that "a close, sensitive relationship with the ... custodial parent" had "centrality" (p. 311) and that the relationship with the noncustodial parent could therefore be discounted, have recently arrived at the opposite conclusion: that "whatever is good for the custodial parent is good for the child" (Baures v. Lewis, 2001, p. 222). However, Warshak (2000) has argued that Wallerstein miscast the voluminous social science literature, and certainly the matter appears more nuanced than such judicial language suggests. For example, although Amato and Gilbreth (1999) found, on the basis of their meta-analysis of 63 studies of divorcing children, no significant association between the frequency of father-child contact and child outcomes, they also found evidence that better outcomes for children, in both academic achievement and frequency of behavioral problems, are associated with authoritative parenting by noncustodial fathers. Moreover, they found that more recent studies have found more benefits of noncustodial parent contact than older studies, suggesting that "noncustodial fathers might be enacting the parent role more successfully now than in the past, with 
beneficial consequences for children" (Amato, 2000, p. 1280). On the other hand, it also appears that noncustodial fathers, at least in past decades, did not usually engage in authoritative parenting, because that kind of relationship is more difficult to maintain for a parent who does not live with the child (Marsiglio, Amato, Day, \& Lamb, 2000); nonetheless, the child's relocation to a considerable distance from the noncustodial parent may make such a relationship not merely more difficult but essentially impossible. More recently, Kelly and Lamb (2003) concluded that "there is substantial evidence that children are more likely to attain their psychological potential when they are able to develop and maintain meaningful relationships with both of their parents, whether or not the two parents live together" (p. 196).

Ironically, cases like Baures v. Lewis (2001) are also inconsistent with Wallerstein's own conclusions, in publications that precede her brief in In re the Marriage of Burgess (1996), as Warshak has shown. For example, in 1980 Wallerstein stated that

our findings regarding the centrality of both parents to the psychological health of children and adolescents alike leads [sic] us to hold that, where possible, divorcing parents should be encouraged and helped to shape postdivorce arrangements which permit and foster continuity in the children's relations with both parents. (Wallerstein \& Kelly, 1980, p. 311).

In sum, recent judicial conclusions concerning the impact of the noncustodial father's relationship with the child on the child's development were not entirely consistent with the psychological evidence, nor even with the prelitigation conclusions of the researcher on whose description of that evidence they relied. The current study adds to that discrepancy because its comparison of children of divorced families that did and did not move provides no evidence that the child is benefited by moving away with the custodial parent.

\section{Implications for Application and Public Policy}

We must note that no data can free the judicial system from the difficult problem of finding a workable and acceptable remedy for the parent who reasonably objects to the other parent's move. The problem arises from the law's understandable resistance to orders that directly restrict a parent's right to move. A court may change the custodial arrangement because of the move, effectively controlling the child's mobility by moving primary custody to the parent who does not move, but it will not bar the initial custodial parent from moving by herself. For the same reason, it will not bar a noncustodial parent from moving, even if the move effectively precludes that parent from exercising his visitation rights, and even if it were persuaded that the child suffers detriment from that parent's move. In extreme cases, of course, the law can terminate the parental status of a reluctant parent. The man who, for example, moves far from his child, never sees or acknowledges her, and does not contribute to her support may have his parental rights terminated, freeing the child for adoption by the mother's new husband. But the law has no effective method for requiring a man (or a woman) to nurture and love a child.

This reality means that the primary tool available to courts that believe a proposed move is not in the child's interests is the strategic use of a conditional change-ofcustody order. Such orders have disadvantages. They are of no value in restraining moves by noncustodial parents, which appear from our data generally as harmful to the child as custodial parent moves, and (as explained in the introduction) their use may seem doctrinally inconsistent with the prevailing view that nonconsensual changes in primary custody are disfavored, and perhaps ordered only when needed to protect the child from some demonstrable detriment in the existing custodial arrangement. For these reasons, recent legal trends discourage their use, as recounted in the introduction.

Yet perhaps our data suggest a reconsideration of this trend. From the perspective of the child's interests, there may be real value in discouraging moves by custodial parents, at least in cases in which the child enjoys a good relationship with the other parent and the move is not prompted by the need to otherwise remove the child from a detrimental environment. And other recent data (Braver, Cookston, \& Cohen, 2002) suggest that these conditional orders would in fact prevent the move in up to two thirds of the cases.

The dilemma resulting from the modern trend is well exemplified in Marriage of Bryant (2001), a California appeals court case applying In re the Marriage of Burgess (1996). At their divorce, the mother, who had always been the children's primary parent, sought primary custody and announced her intention to move with them from Santa Barbara to New Mexico, where her family lived. Since the parents' separation, the father had seen the children, 6 and 9 years of age, three or four times weekly, as well as talking with them daily on the phone. All agreed that his relationship with the children was important to them as well as to him, but all also agreed that the mother was a good parent with a close emotional bond with her children. Father earned a good income and had the financial capacity to fly regularly to New Mexico to visit the children, but he could not move there without considerable financial sacrifice. It seemed clear that the episodic paternal contact that would be possible if the children moved to New Mexico would be a poor substitute for the daily involvement in his children's life that the father maintained in Santa Barbara. Mother was the beneficiary of a trust fund and had no financial pressure requiring her move, which the court's appointed expert described as motivated by her desire to "escape a failed marriage." Her move to New Mexico was not badly intentioned, although a bad parenting decision according to both the court's expert and the parties' therapist. The trial judge observed:

There are two realistically possible scenarios in this case. The court could conditionally grant physical custody of the children to the father (with liberal visitation to the mother) if the mother moves away, with joint physical custody if the mother remains in Santa Barbara. In all likelihood, the court could force the joint-physical-custody scenario, since it is unlikely 
that mother will move away if it means she thereby becomes the non-custodial parent. This would be the optimum scenario for the best interests of the children, since it would preserve their lifelong social structure in the Santa Barbara area with very successful schooling, church, sports, paternal extended family and maternal aunt and would maximize the children's frequent and continuing contact with both parents. (Marriage of Bryant, 2001, p. 797)

But the trial judge nonetheless concluded he was compelled by Burgess to deny the father's petition for the conditional change of custody order, and "select what is next best in the children's interest"-maintaining primary custody with the mother in New Mexico. The intermediate court of appeals, also bound by Burgess, agreed and affirmed the trial judge:

Having found that [mother] was not acting in bad faith and that it is in the best interests of the children for custody to be with [her], the trial court was bound to rule as it did. We agree with the dissent that Burgess is disquieting because in cases such as this one it leaves the children with the second best solution. (Marriage of Bryant, 2001, p. 797)

Clearly, no court should issue a conditional change-ofcustody order if it believes that any custodial change would yield important disadvantages for the child. But on the other hand, it may also be poor policy to insist that such orders be denied unless the noncustodial parent shows that the current custodial parent's home has some detrimental impact on the child, as is often required for ordinary petitions to change a child's primary custody. Certainly, if further studies were to support the causal inference-were to show that moves by custodial parents have a substantial harmful causal impact on their children - then the child's separate interests would seem to require this reconsideration.

\section{References}

Alfieri v. Alfieri. 733 P. 2d 4 (N.M. Ct. App. 1987).

Amato, P. (1993). Childrens' adjustment to divorce: Theories, hypotheses, and empirical support. Journal of Marriage and the Family, 55, 23-28.

Amato, P. R. (2000). The consequences of divorce for adults and children. Journal of Marriage and the Family, 62, 1269-1287.

Amato, P. R., \& Booth, A. (1996). A prospective study of divorce and parent-child relationships. Journal of Marriage and the Family, 58, 356-365.

Amato, P. R., \& Gilbreth, J. G. (1999). Nonresident fathers and children's well-being: A meta-analysis. Journal of Marriage and the Family, 61, 557-573.

American Academy of Matrimonial Lawyers. (1998). American Academy of Matrimonial Lawyers proposed model relocation act: An act relating to the relocation of the principal residence of the child. Journal of the American Academy of Matrimonial Lawyers, 15, 1-24.

American Law Institute. (2002). Principles of the law of family dissolution: Analysis and recommendations. Dayton, OH: LexisNexis.

Andrews, F. M., \& Withey, S. B. (1976). Social indicators of well-being: Americans' perceptions of life quality. New York: Plenum.

Austin, W. G. (2000a). A forensic psychology model of risk assessment for child custody relocation law. Family and Conciliation Courts Review, 38, 192-207.
Austin, W. G. (2000b). Relocation law and the threshold of harm: Integrating legal and behavioral perspectives. Family Law Quarterly, 34, 63-82.

Baker, R. W., \& Siryk, B. (1989). Student Adaptation to College Questionnaire manual. Los Angeles: Western Psychological Services.

Barefoot, J. C., Larsen, S., von der Lieth, L., \& Schroll, M. (1995). Hostility, incidence of acute myocardial infarction, and mortality in a sample of older Danish men and women. American Journal of Epidemiology, 142, 477-484.

Baures v. Lewis, 167 N.J. 91;770 A.2d 214 (N.J. 2001).

Bauserman, R. (2002). Child adjustment in joint-custody versus sole-custody arrangements: A meta-analytic review. Journal of Family Psychology, 16, 91-102.

Bollen, K., \& Lennox, R. (1991). Conventional wisdom on measurement. A structural equation perspective. Psychological Methods, 110, 305-314.

Braver, S. L., Cookston, J. T., \& Cohen, B. R. (2002). Experiences of family law attorneys with current issues in divorce practice. Family Relations, 51, 325-334.

Braver, S. L., Hipke, K. N., Ellman, I. M., \& Sandler, I. N. (in press). Strengths-building public policy for children of divorce. In G. Leadbetter, K. Maton, C. H. Schellenbach, \& A. S. Solarz, (Eds.), Strengths based public policies. Washington, DC: American Psychological Association.

Braver, S. L., \& O'Connell, E. (1998). Divorced dads: Shattering the myths. New York: Tarcher/Putnam.

Bruch, C. S., \& Bowermaster, J. M. (1996). The relocation of children and custodial parents: Public policy, past and present. Family Law Quarterly, 30, 245-303.

Bumpass, L. L., \& Sweet, J. A. (1989). Children's experience in single-parent families: Implications of cohabitation and marital transitions. Family Planning Perspectives, 21, 256-260.

Coatsworth, D. (2000). Emotional, instrumental and financial support by divorced parents of their college aged children. Unpublished honors thesis, Arizona State University.

Cook, W., \& Medley, D. (1957). Proposed hostility and pharisaicvirtue scales for the MMPI. Journal of Applied Psychology, 38, 414-418.

Cooper v. Roe, 23 Cal.Rptr.2d 295, 299 (Cal. App. 1993).

Davis, M. C., Matthews, K. A., \& McGrath, C. E. (2000). Hostile attitudes predict elevated vascular resistance during interpersonal stress in men and women. Psychosomatic Medicine, 62, 17-25.

DeBellis, M. D., Baum, A. S., Birmaher, B., Keshavan, M. S., Eccard, C. H., Boring, A. M., et al. (1999). Developmental traumatology: Part I. Biological stress systems. Biological Psychiatry, 45, 1259-1270.

Deneau, K. A. (1999). Older children's relationships with their parents post divorce and parents' flexibility with visitation schedules. Unpublished honor's thesis, Arizona State University.

DiPietro, J. A. (2000). Baby and the brain: Advances in child development. Annual Review of Public Health, 21, 455-471.

Ellman, I. M., Kurtz, P., \& Scott, E. (1998). Family law: Cases, text, problems. Charlottesville, VA: Lexis Law Publishing.

Elrod, L. D., \& Spector, R. G. (1997). A review of the year in family law: Of welfare reform, child support, and relocation. Family Law Quarterly, 30, 765-809.

Engebretson, T. O., \& Matthews, K. A. (1992). Dimensions of hostility in men, women, and boys: Relationships to personality and cardiovascular responses to stress. Psychosomatic Medicine, 54, 311-323.

Everett v. Everett, 660 So.2d 599, 601 (Ala. Civ. App. 1995). Fabricius, W. V. (in press). Listening to children of divorce: New 
findings on living arrangements, college support and relocation that rebut Wallerstein, Lewis and Blakeslee. Family Relations.

Fabricius, W. V., Braver, S. L., \& Deneau, K. (2003). Divorced parents' financial support of their children's college expenses. Family Court Review, 41, 224-241.

Fabricius, W. V., \& Hall, J. (2000). Young adults' perspectives on divorce: Living arrangements. Family and Conciliation Courts Review, 38, 446-461.

Ford, C. (1997). Untying the relocation knot: Recent developments and a model for change. Columbia Journal of Gender and Law, 7, 1-53.

Gindes, M. (1998). The psychological effects of relocation for children of divorce. Journal of the American Academy of Matrimonial Lawyers, 15, 119-148.

Goede, M., \& Spruijt, E. (1996). Effects of parental divorce on youth unemployment on adolescent health. Patient Education and Counseling, 29, 269-276.

Gould v. Miller, 488 N.W.2d 42, 43 (N.D. 1992).

Gunnar, M. R. (1998). Quality of early care and buffering of neuroendocrine stress reactions: Potential effects on the developing human brain. Preventive Medicine, 27, 208-211.

Heim, C., Newport, D. J., Heit, S., Graham, Y. P., Wilcox, M., Bonsall, R., et al. (2000). Pituitary-adrenal and autonomic responses to stress in women after sexual and physical abuse in childhood. JAMA, 284, 592-597.

Hensgens v. Hensgens, 653 So.2d 48, 56-57 (La. Ct. App. 1995). Holder v. Polanski, 544 A.2d 852, 856 (N.J. 1988).

Humke, C., \& Schaeffer, C. (1995). Relocation: A review of the effects of residential mobility on children and adolescents. Psychology: A Journal of Human Behavior, 32, 16-24.

Idler, F. L., \& Benyamini, Y. (1997). Self-rated health and mortality: A review of twenty-seven community studies. Journal of Health and Social Behavior, 38, 21-37.

In re Carlson, 280 Cal.Rptr. 840, 844, 946 (Cal. App. 1991).

In re the Marriage of Burgess, 913 P.2d 473 (Cal. 1996).

Jaramillo v. Jaramillo, 823 P.2d 299, 305 (N.M. 1991).

Jordan, W. J., Lara, J., \& McPartland, J. M. (1996). Exploring the causes of early drop-out among race-ethnic and gender groups. Youth \& Society, 28, 62-94.

Kamarck, T. W., Everson, S. A., Kaplan, G. A., Manuck, S. B., Jennings, J. R., Salonen, R., \& Salonen, J. T. (1997). Exaggerated blood pressure responses during mental stress are associated with enhanced carotid atherosclerosis in middle-aged Finnish men. Circulation, 96, 3842-3848.

Kelly, J. B., \& Lamb, M. E. (2003). Developmental issues in relocation cases involving young children: When, whether, and how? Journal of Family Psychology, 17, 193-205.

LaChapelle v. Mitten, 607 N.W.2d 151, 162-63 (Minn. Ct. App. 2000).

Lamb v. Wenning, 600 N.E.2d 96 (Ind. 1992).

Lane v. Schenk, 614 A.2d 786, 790-92 (Vt. 1992).

Laumann-Billings, L., \& Emery, R.E. (2000). Distress among young adults from divorced families. Journal of Family Psychology, 14, 671-687.

Levine, M. (1966). Residential change and school adjustment. Community Mental Health Journal, 2, 61-69.

Lozinak v. Lozinak, 569 A.2d 353 (Pa. Super. Ct. 1990).

Luecken, L. J. (1998). Childhood attachment and loss experiences affect adult cardiovascular and cortisol function. Psychosomatic Medicine, 60, 765-772.

Luecken, L. J. (2000a). Attachment and loss experiences during childhood are associated with adult hostility, depression, and social support. Journal of Psychosomatic Research, 49, 85-91.

Luecken, L. J. (2000b). Parental caring and loss during childhood and adult cortisol responses to stress. Psychology and Health, 15, 841-851.

Luecken, L. J., \& Fabricius, W. V. (in press). Hostility, somatic symptoms, and illness reports in adult children from divorced and intact families. Journal of Psychosomatic Research.

Lye, D. N., Klepinger, D. H., Hyle P. D., \& Nelson, A. (1995). Childhood living arrangements and adult children's relations with their parents. Demography, 32, 261-280.

Maeda v. Maeda, 794 P.2d 268 (Haw. Ct. App. 1990).

Marriage of Bryant, 110 Cal.Rptr.2d 791 (App. 2001).

Marsiglio, W., Amato, P. R., Day, R. D., \& Lamb, M. E. (2000). Scholarship on fatherhood in the 1990s and beyond. Journal of Marriage and the Family, 62, 1173-1191.

Matthews, K. A., Woodall, K. L., Kenyon, K., \& Jacob, T. (1996). Negative family environment as a predictor of boys' future status on measures of hostile attitudes, interview behavior, and anger expression. Health Psychology, 15, 30-37.

Mechanic, D., \& Hansell, S. (1989). Divorce, family conflict, and adolescents' well-being. Journal of Health and Social Behavior, 30, 106-116.

Meyer, D. R., \& Garasky, S. (1993). Custodial fathers: Myths, realities, and child support policy. Journal of Marriage and the Family, 55, 73-89.

Miller, S. (1995). Whatever happened to the "best interests" analysis in New York relocation cases? Pace Law Review, 15, 339-389.

Moore v. Moore, 585 So.2d 66, 68 (Ala. Civ. App. 1991).

National Center for Health Statistics. (1990). Vital statistics of the United States, 1988: Vol. 1. Natality (DHHS Publication No. PHS-90-1100). Washington, DC: U.S. Government Printing Office.

National Conference of Commissioners on Uniform State Laws. (1974). Uniform Marriage and Divorce Act $\S \S 101-309,9 A(1)$ U.L.A. $159 \S \S 310-506,9 A(2)$ U.L.A. 1 (1988 \& Supp. 1999).

Nord, C. W., \& Zill, N. (1997). Non-custodial parents' participation in their children's lives. Child Support Report, 19, 1-2.

Richards, J. L. (1999). Children's rights vs. parents' rights: A proposed solution to the custodial relocation conundrum. New Mexico Law Review, 29, 245-287.

Rotman, A. S., Tompkins, R., Schwartz, L. L., \& Samuels, M. D. (2000). Reconciling parents' and children's interests in relocation: In whose best interest? Family and Conciliation Courts Review, 38, 341-367.

Russek, L. G., Schwartz, G. E., Bell, I. R., \& Baldwin, C. M. (1998). Positive perceptions of parental caring are associated with reduced psychiatric and somatic symptoms. Psychosomatic Medicine, 60, 654-657.

Sample, T., \& Reiger, T. (1998). Relocation standards and constitutional considerations. Journal of the American Academy of Matrimonial Lawyers, 15, 229-243.

Shear, L. E. (1996). Life stories, doctrines, and decision making: Three high courts decide the move-away dilemma. Family and Conciliation Courts Review, 34, 439-458.

Siegler, I. C., Peterson, B. L., Barefoot, J. C., \& Williams, R. B. (1992). Hostility during late adolescence predicts coronary risk factors at mid-life. American Journal of Epidemiology, 36, 146154.

Sobie, M. (1995). Whatever happened to the "best interests" analysis in New York relocation cases? A response. Pace Law Review, 15, 685-701.

Stokols, D., \& Shumaker, S. A. (1982). The psychological context of residential mobility and well-being. Journal of Social Issues, 38, 149-171.

Stolberg, A. L., \& Anker, J. M. (1983). Cognitive and behavioral 
changes in children resulting from divorce and consequent environmental changes. Journal of Divorce, 7, 23-32.

Sullivan v. Sullivan, 594 N.Y.S.2d 276 (N.Y. App. Div. 1993).

Taylor v. Taylor, 849 S.W.2d 319, 321 (Tenn. 1993).

Terry, E. J., Proctor, K. K., Phelan, P. C., \& Womack, J. L. (1998). Relocation: Moving forward or moving backward? Journal of the American Academy of Matrimonial Lawyers, 15, 167-228.

Tessman, L. H. (1978). Children of parting parents. New York: Jason Aronson.

Tropea v. Tropea, 665 N.E.2d 145, 148 (N.Y. 1996).

Troxel v. Granville, 120 S. Ct. 2054 (2000).

Tucker, J., Marx, J., \& Long, L. (1998). "Moving on": Residential mobility and children's school lives. Sociology of Education, 71, 111-129.

U.S. Bureau of the Census. (2000, January). Current Population Reports P20-520: Geographical mobility. Washington, DC: U.S. Government Printing Office.

Wallerstein, J. S., (1995). Amica Curiae Brief of Dr. Judith S. Wallerstein, Ph.D., Filed in Cause No. S046116, In re the Marriage of Burgess, Supreme Court of the State of California, Dec. 7, 1995.

Wallerstein, J. S., \& Kelly, J.B. (1980) Surviving the breakup. New York: Basic Books.
Wallerstein, J. S., \& Tanke, T. J. (1996). To move or not to move: Psychological and legal considerations in the relocation of children following divorce. Family Law Quarterly, 30, 305-332.

Warshak, R. A. (1999). Relocation litigation and children's best interests: Revisiting Burgess. State Bar of Texas Section Report: Family Law, 4, 8-12.

Warshak, R. A. (2000). Social science and children's best interests in relocation cases: Burgess revisited. Family Law Quarterly, 34, 83-113.

White v. White, 437 Pa.Super. 446, 650 A.2d 110, 113 (Pa. Super. Ct. 1994).

Williams, R. B. (1997). The role of psychosocial factors in human disease: Lessons from animal models. Acta Physiologica Scandinavia Supplement, 640, 100-102.

Wis. Stat. Ann. § 767.327 (3) (c) (1) (West Supp. 1998).

Wolchik, S., Sandler, I. N., Braver, S. T., \& Fogas, B. (1985). Events of parental divorce: Stressfulness ratings by children, parents, and clinicians. American Journal of Community Psychology, 14, 59-74.

Received December 21, 2001

Revision received May 23, 2002

Accepted July 11, 2002

\section{Low Publication Prices for APA Members and Affiliates}

Keeping you up-to-date. All APA Fellows, Members, Associates, and Student Affiliates receive-as part of their annual dues-subscriptions to the American Psychologist and APA Monitor. High School Teacher and International Affiliates receive subscriptions to the APA Monitor, and they may subscribe to the American Psychologist at a significantly reduced rate. In addition, all Members and Student Affiliates are eligible for savings of up to $60 \%$ (plus a journal credit) on all other APA journals, as well as significant discounts on subscriptions from cooperating societies and publishers (e.g., the American Association for Counseling and Development, Academic Press, and Human Sciences Press).

Essential resources. APA members and affiliates receive special rates for purchases of APA books, including the Publication Manual of the American Psychological Association, and on dozens of new topical books each year.

Other benefits of membership. Membership in APA also provides eligibility for competitive insurance plans, continuing education programs, reduced APA convention fees, and specialty divisions.

More information. Write to American Psychological Association, Membership Services, 750 First Street, NE, Washington, DC 20002-4242. 